\title{
Different Loading Systems for Reinforced Earth Walls under Strip Footing Load
}

\author{
Hamzeh Ahmadi, Adam Bezuijen \\ Ghent University \\ Technologiepark 905, B-9052 Zwijnaarde, Ghent, Belgium \\ hamzeh.ahmadi@ugent.be; adam.bezuijen@ugent.be
}

\begin{abstract}
In this paper the behavior of reinforced earth walls with rigid and flexible faces under strip footing load was studied by numerical analysis. In one numerical model the strip footing load was free to have horizontal and vertical movements and in another the horizontal movement of the strip footing load was restricted. By considering these two different models, the results of 2D and 3D numerical analysis (Plaxis) were compared with the full scale test results about the horizontal earth pressures, lateral wall deflections and consequently maximum tensile force on reinforcement layers. For modeling the compaction loads in each layer two equal distributed loads were considered in the top and bottom of each soil layer and also the influence of sidewall friction was studied in a 3D numerical analysis. Results showed that there is good agreement between 3D numerical analysis and full scale test results by considering the horizontal restriction for the strip footing load.
\end{abstract}

Keywords: Full scale model tests, Reinforced earth walls, Strip footing load, Horizontal restriction, Numerical analysis

\section{Introduction}

The behavior of reinforced earth structures has been comprehensively studied through field observations and full-scale physical model, laboratory model testing, and numerical simulation (Frankowska [1]; Bergado and Teerawattanasuk [2]; Hatami and Bathurst [3,4]; Won and Kim [5]). 2D numerical analysis by considering the plane strain condition for reinforced earth structures was done by Bergado et al. [6]; Karpurapu and Bathurst [7]; Chai et al. [8]; Rowe and Ho [9]). Some researchers considered the compaction effect by applying only a surcharge load over the soil layers (Gotteland et al. [10]; Hatami and Bathurst [3, 4]; Huang et al. [11]) in numerical analysis. However, Ehrlich and Mirmoradi [12], Ehrlich et al. [13] and Mirmoradi and Ehrlich, $[14,15]$ modeled the compaction load with using two equal distributed loads at the top and bottom of each soil layers.

Some experimental studies of strip footing, retaining wall and reinforced backfill in the reduced scale are done by Pinto and Cousens [16] Pinto and Cousens [17], Shinde and Mandal [18], Mittal et al. [19] and Ahmadi and HajialilueBonab [20]. Physical models in this study were prepared and tested at Brandenburg University of Technology CottbusSenftenberg (Pachomov et al. [21]).

Some studies showed that the reinforcement also leads to an improvement of the soil strength. This is modelled as an apparent cohesion (Yang [22], Schlosser and Long [23]). Also Jonathan and Pham [24] considered this apparent cohesion in GRS walls by using empirical relationship between the maximum particle size in soil and reinforcement layers space.

Ahmadi and Bezuijen [25] considered this apparent cohesion for numerical analysis. They showed that by taking into account this apparent cohesion also there is good agreement between the full scale test results and Plaxis 2D analysis. However, there are only a limited number of $3 \mathrm{D}$ numerical studies about the full scale reinforced soil structures under the strip footing load to consider the effect of sidewalls friction and the strip footing load. In the new method described in this paper, without considering the apparent cohesion for modeling soil-geosynthetic composite behavior in numerical analysis, two different strategies can be considered to simulate the strip footing load; one with considering the horizontally free condition and another with horizontally restricted condition.

In this study the behavior of the strip footing load on the backfill of reinforced earth structure also depends on the compaction load, flexibility of the facing panel. 


\section{Full scale and Numerical Models}

\subsection{Preparing the models}

In this study the full-scale laboratory test results (two mechanically stabilized earth walls, one with plywood and one with full height concrete facing) are compared with the results of 2D and 3D numerical analysis. The instrumentation and configuration of the walls are shown in Error! Reference source not found.. The physical model was $4 \mathrm{~m}$ high. The backfill soil in the test condition was compacted in layers prior to the test using a vibrating plate. The horizontal pressure was measured at different locations from the facing panel $(\mathrm{a}=0.05,0.38,0.71$ and $1.04 \mathrm{~m})$. After finishing the backfill construction also the strip footing load was applied over the backfill in the area shown in Fig. 2. The strain gauges on the reinforcement layers are shown in Error! Reference source not found.. The locations of these strain gauges were $\mathrm{a}=0.08,0.32,0.56,0.8$ and $1.04 \mathrm{~m}$ from the facing panel.

The numerical modeling was carried out using the two and three dimensional finite-element program Plaxis (Brinkgreve and Vermeer [26]). With 3-D Plaxis calculations the influence of side wall friction can also be considered. The same dimensions and boundary conditions as present in the full scale physical tests were used. The soil properties used were determined by separate tests.

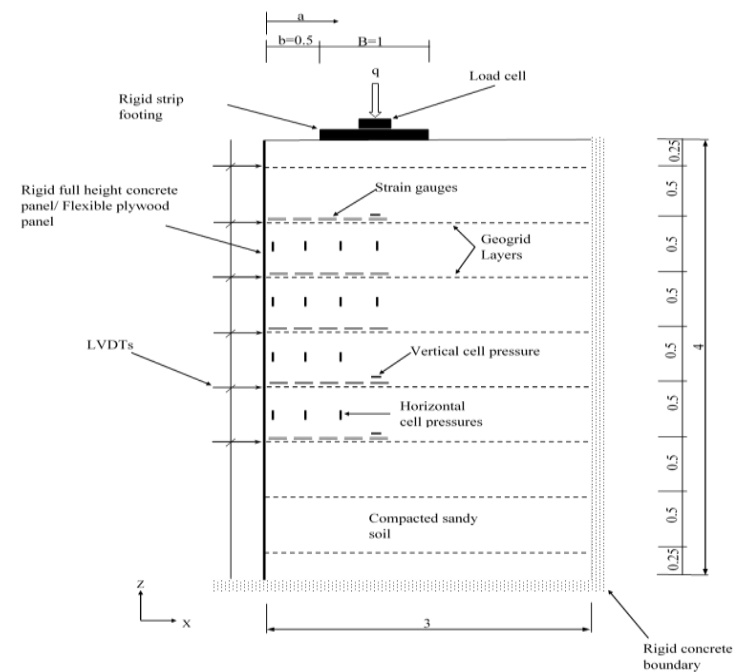

Fig. 1: Test layout for full scale models and instruments (all dimensions are in $\mathrm{m}$ ).

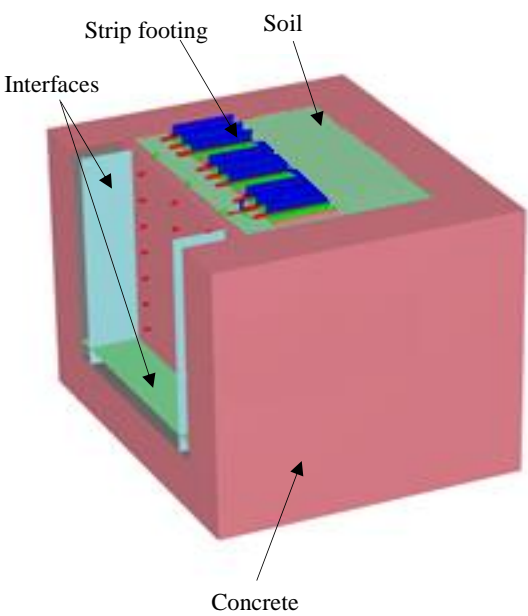

Fig. 2: 3D Numerical model with concrete material around the backfill and for the wall face. 
The equivalent dynamic load (two times of static load) of the compactor used in the numerical analysis is $50 \mathrm{kPa}$ for plate compactor. Further details of the experimental and numerical models can be found in Table 1. Maximum strains measured during backfill construction and after applying the strip footing load were as limited to $0.5 \%$ and $2 \%$ respectively. Consequently in this study two different stiffness's with long term condition (1000 hour) and short term condition (1 hour) were considered (in numerical and experimental analysis). Error! Reference source not found. shows the details about the rigid concrete wall in the 3D numerical model. A Hardening soil model was applied for numerical analysis. Secant modulus $\mathrm{E}_{50}^{\mathrm{ref}}$ and young's modulus for unloading and reloading $\mathrm{E}_{\mathrm{ur}}^{\mathrm{ref}}$ are determined from a triaxial stressstrain-curve. The geogrid reinforcement (GR) was modeled as a linear elastic material and with reinforcement-soil interface friction angle equal to the soil friction angle. Rowe and Ho [9] considered the perfect adherence as a reasonable assumption for the soil-geogrid interface friction coefficient $\left(\delta_{\mathrm{s}, \mathrm{r}}=1\right)$ in numerical analysis. For 2D analysis, the plane strain condition and 15-node triangular elements with a fine mesh (3019 elements) were used and for the 3D numerical (32141) elements.

To get more accurate results and minimizing the effect of the mesh size on the system, the mesh was refined around the reinforcement layers, strip footing and facing panel. In this analysis, the reinforced concrete wall was assumed to be a linearly-elastic material with a modulus of elasticity of $2 \mathrm{E} 7 \mathrm{KN} / \mathrm{m} 2$ and a Poisson's ratio of 0.2 . This allows to model correctly the base condition of the rigid wall face. Under the base of the wall, the friction angle coefficient of the rough concrete-concrete was applied by using an interface element in both the 2D and 3D numerical analysis. Soil layers were 'placed' every $0.20 \mathrm{~m}$ and 'compacted' until the final wall height was achieved. For modeling the compaction effect in every new layer of backfill, a temporary uniform load with 50kPa have been applied to the top and bottom of each backfill layer for both models. The stiffness of the GR was measured in accordance with DIN EN ISO 10319:2008 ([27]) with considering the short term and long term loading condition.

Table 1: Input parameters for Plaxis analysis.

\begin{tabular}{|c|c|c|}
\hline Parameter & Symbol & Value \\
\hline Wall height $(\mathrm{m})$ & $\mathrm{H}$ & 4 \\
\hline Unit weight-soil (kN/m3) & $\gamma_{\mathrm{s}}$ & 17.3 \\
\hline Reinforcement length (m) & $\mathrm{L}$ & 3 \\
\hline Vertical spacing of reinforcement $(\mathrm{m})$ & $\mathrm{Sv}$ & 0.25 and 0.5 \\
\hline Long term (1000 hour) stiffness of reinforcements $(\varepsilon \leq 0.5 \%)(\mathrm{kN} / \mathrm{m})$ & EA & 670 \\
\hline short term (1 hour) stiffness of reinforcements $(\varepsilon \leq 2 \%)(\mathrm{KN} / \mathrm{m})$ & EA & 700 \\
\hline Young's modulus for unloading and reloading $(\mathrm{kN} / \mathrm{m} 2)$ & $\mathrm{E}_{\mathrm{ur}}^{\mathrm{ref}}$ & 112000 \\
\hline Secant modulus & $\mathrm{E}_{50}^{\mathrm{ref}}$ & 42500 \\
\hline Tangent stiffness & $\mathrm{E}_{\text {oed }}^{\text {ref }}$ & 38500 \\
\hline Power & $\mathrm{m}$ & 0.5 \\
\hline Failure ratio & $\mathrm{R}_{f}$ & 0.74 \\
\hline Soil Poisson's ratio & $v_{\mathrm{s}}$ & 0.3 \\
\hline Concrete and plywood wall bending stiffness $(\mathrm{kNm} 2 / \mathrm{m})$ & EI & $20 \mathrm{E} 3,20.25$ \\
\hline Concrete and plywood wall normal stiffness $(\mathrm{kN} / \mathrm{m})$ & EA & 6.0E6, 2.7E5 \\
\hline Estimated soil plane strain friction angle (Wroth [28]) $\left(^{\circ}\right)$ & $\varphi_{p s}$ & 44 \\
\hline Peak soil friction angle from the triaxial test $\left(^{\circ}\right)$ & $\varphi_{t x}$ & 39.09 \\
\hline Residual friction angle from the triaxial test $\left(^{\circ}\right)$ & $\varphi_{r}$ & 35.15 \\
\hline Soil dilation angle from the test $\left(^{\circ}\right)$ & $\psi$ & 12.5 \\
\hline Soil to nylon coefficient of friction angle $\left({ }^{\circ}\right)$ & $\varphi_{s w}$ & 11.5 \\
\hline Soil-reinforcement friction angle coefficient & $\delta_{\mathrm{s}, \mathrm{r}}$ & 1 \\
\hline Soil-concrete friction angle coefficient & $\delta_{\mathrm{S}, \mathrm{c}}$ & 0.55 \\
\hline Rough concrete-concrete friction angle coefficient & $\delta_{\mathrm{c}, \mathrm{c}}$ & 0.95 \\
\hline Soil-wood friction angle coefficient & $\delta_{\mathrm{s}, \mathrm{w}}$ & 0.45 \\
\hline Concrete young's modulus (kN/m2) & $\mathrm{E}_{\mathrm{c}}$ & $2.1 \mathrm{E} 8$ \\
\hline Cohesion-soil $(\mathrm{kPa})$ & $\mathrm{C}$ & 0 \\
\hline Unit weight-concrete $(\mathrm{kN} / \mathrm{m} 3)$ & $\gamma_{c}$ & 24 \\
\hline Concrete and wood Poisson's ratio & $v_{\mathrm{c}}, v_{\mathrm{w}}$ & $0.2,0.33$ \\
\hline
\end{tabular}




\subsection{Lateral earth pressure}

In Fig. 3, the experimental and 3D numerical analysis results were compared by considering the different conditions for the strip footing load (horizontally restricted and free condition). For the lateral earth pressure in different locations behind the wall and under the strip footing load $(\mathrm{q}=300 \mathrm{KN} / \mathrm{m})$ there is good agreement between the numerical analysis $(\mathrm{P}(\mathrm{r}))$ and test results $(\mathrm{T})$ when there is horizontal restriction for strip footing load (thus the load can only move downwards, not horizontal). For lateral earth pressure near the wooden wall face $(\mathrm{a}=0.05 \mathrm{~m})$, the difference between the test results and numerical analysis with horizontally free condition $(\mathrm{P}(\mathrm{f}))$ is more than for the concrete face.

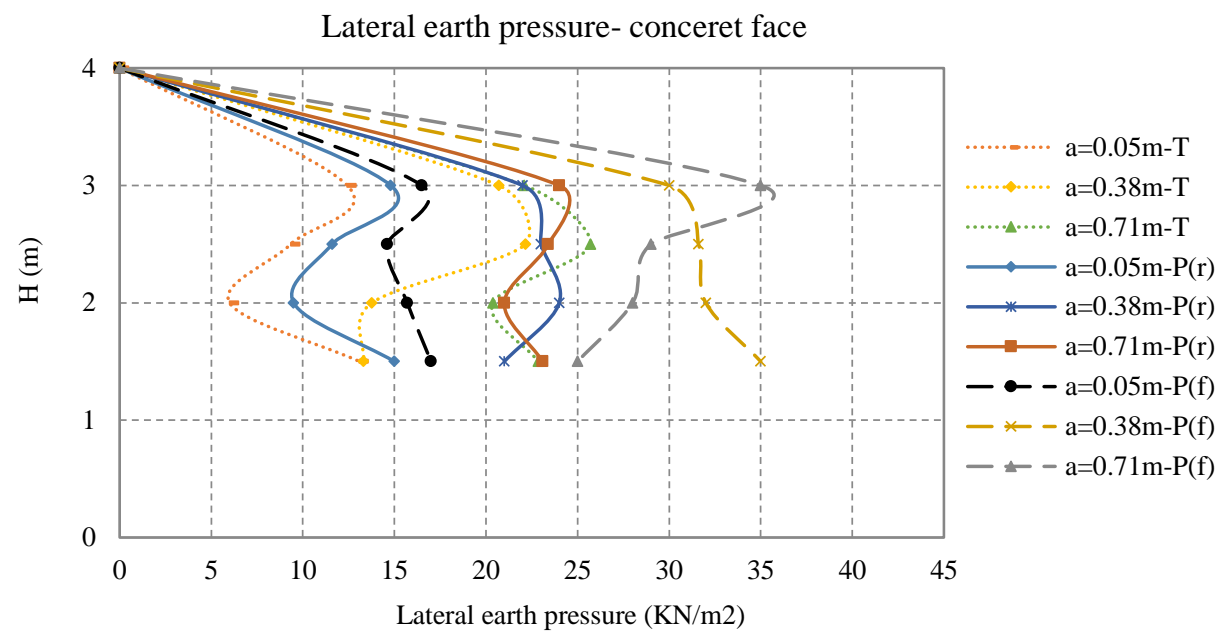

a)

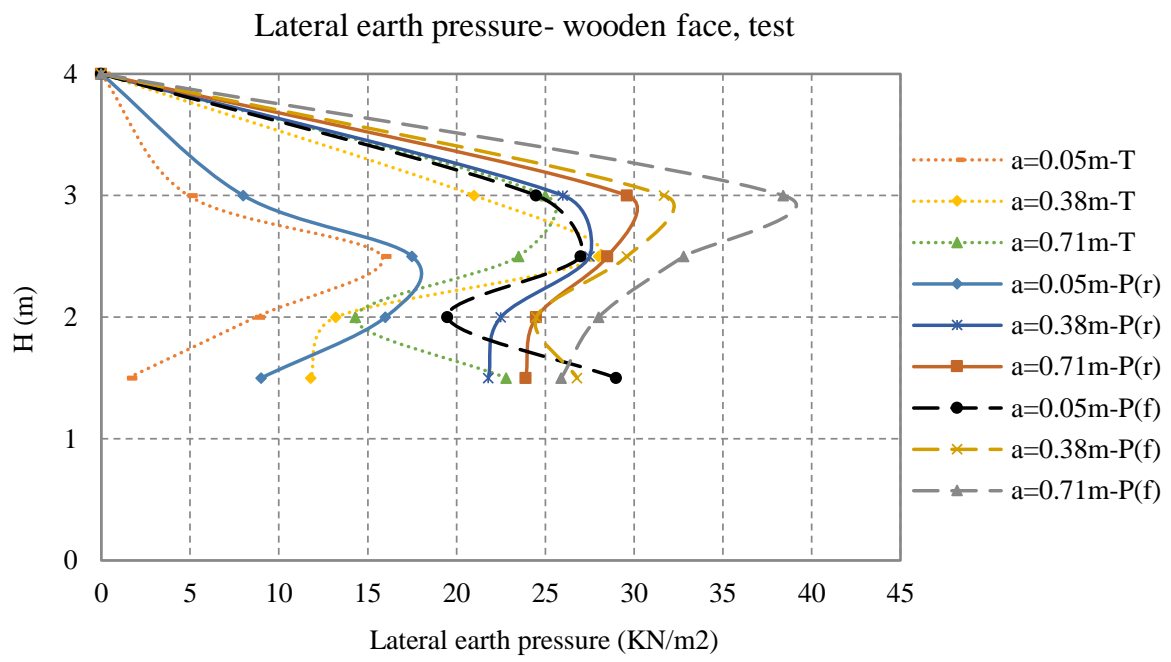

b)

Fig. 3. Lateral earth pressure after applying the strip footing load $(300 \mathrm{kN} / \mathrm{m} 2)$; a) concrete face, b) wooden face.

Lateral earth pressures increase around 1.5 times more in the numerical analysis than in the physical test results assuming the horizontally free condition for strip footing load. For a $=0.05 \mathrm{~m}$ and from the concrete face in the test as well as in the Plaxis analysis, there are two maxima for the lateral earth pressure, one in the upper and another in the deeper position $(\mathrm{h}=1.5$ and $3 \mathrm{~m})$. In the wooden face a maximum in the lateral earth pressure only occurred in the upper position $(\mathrm{h}=2.5 \mathrm{~m})$. Increasing the wall face rigidity results in a maximum lateral earth pressure that is located higher on the wall 
face. Also for $(\mathrm{a}=0.38$ and $0.71 \mathrm{~m})$, the Plaxis analysis shows bigger lateral earth pressure in free condition for strip footing load compared to horizontally fixed loading.

\subsection{Lateral wall deflection}

Fig. $4 \mathrm{a}$ and $\mathrm{b}$, show the lateral wall deflection under the strip footing load and in concrete and wooden face from the test and Plaxis (2D and 3D) analysis results. This measurement shows only the wall deflection after applying the strip footing load (without considering the lateral wall deflection at the end of backfill construction). For the wooden face, the maximum lateral wall deflection occurred in $\mathrm{h} / \mathrm{H}=0.81$ in both the numerical simulation with horizontally free condition for strip footing load and the test and the maximum wall deflection in the wooden face is more than in the concrete face. By comparing the 3D numerical analysis with test results (concrete and wooden face) about the maximum wall deflection in $\mathrm{h} / \mathrm{H}=0.81$, when there is horizontal restriction for strip footing load the calculated wall deflection is around $8 \%$ larger but for horizontally free condition of strip footing load this difference is larger than $40 \%$. For the maximum wall deflection, there is good agreement between the test results and 3D numerical analysis with horizontally restricted condition but the location of the maximum wall deflection in this case is $h / H=0.68$ for wooden face, lower than the measured $\mathrm{h} / \mathrm{H}=0.81$.

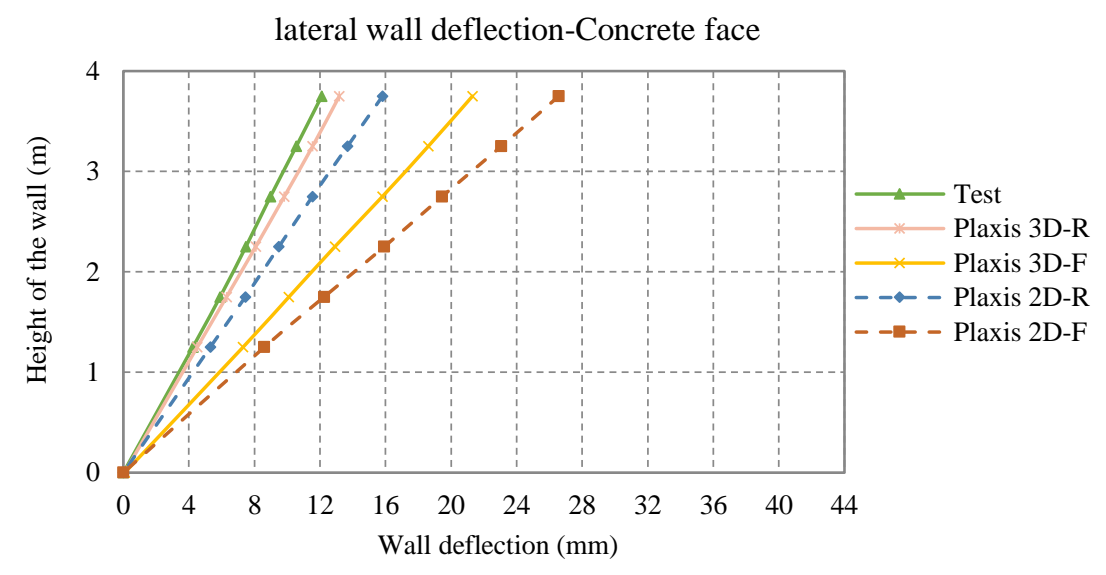

a)

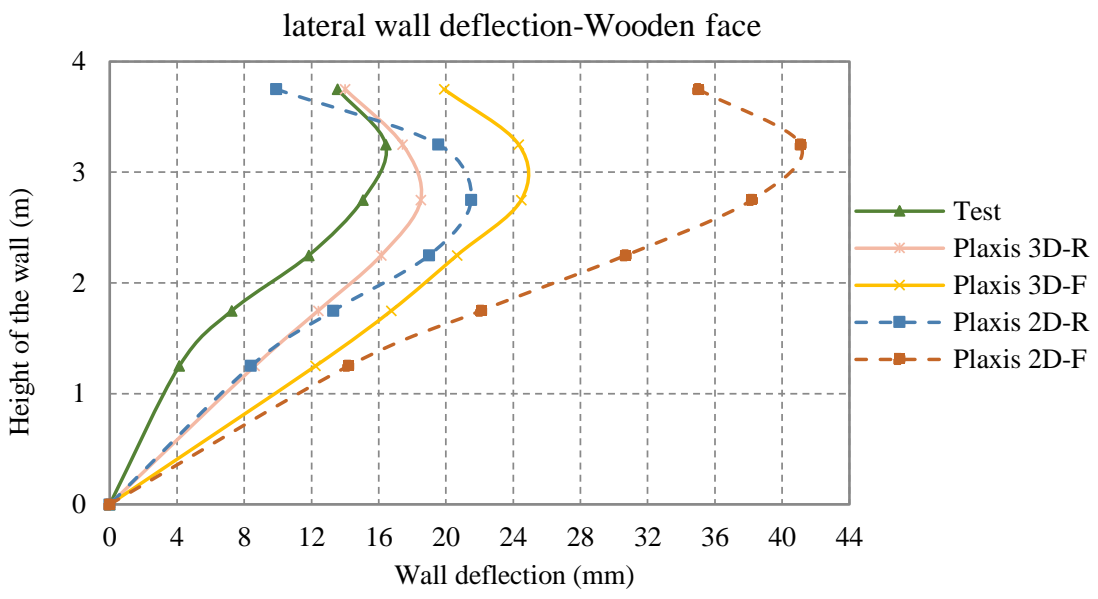

b)

Fig. 4: Lateral wall deflection after applying the strip footing load in experimental and numerical analysis; a) Concrete face, b) wooden face. 


\section{Maximum tensile forces}

Fig. 5a and $\mathrm{b}$ show the maximum tensile load on reinforcement layers from the measured and 2D and 3D numerical analysis after applying the strip footing load. The short term (1 hour) stiffness of the geogrid is used for determining the maximum tensile forces in the reinforcement layers. In Fig. 5a and for the wooden face, the maximum value occurred in $\mathrm{z} / \mathrm{H}=0.81$ (where the maximum wall deflection occurred). This maximum tensile force is larger than in the concrete face in Fig. 5b. For both the concrete and the wooden face, the maximum tensile load decreases in depth, but more outspoken for the concrete face. The maximum tensile loads in the 2D and 3D numerical analysis with horizontally free condition are more than in the test results for both the flexible and stiff-face. By comparing the test with 2D and 3D numerical analysis with respect to the maximum tensile forces in the reinforcement layers, there is also a good agreement between the 3D numerical analysis and test results by considering the horizontal restriction for strip footing load in Fig. 5.

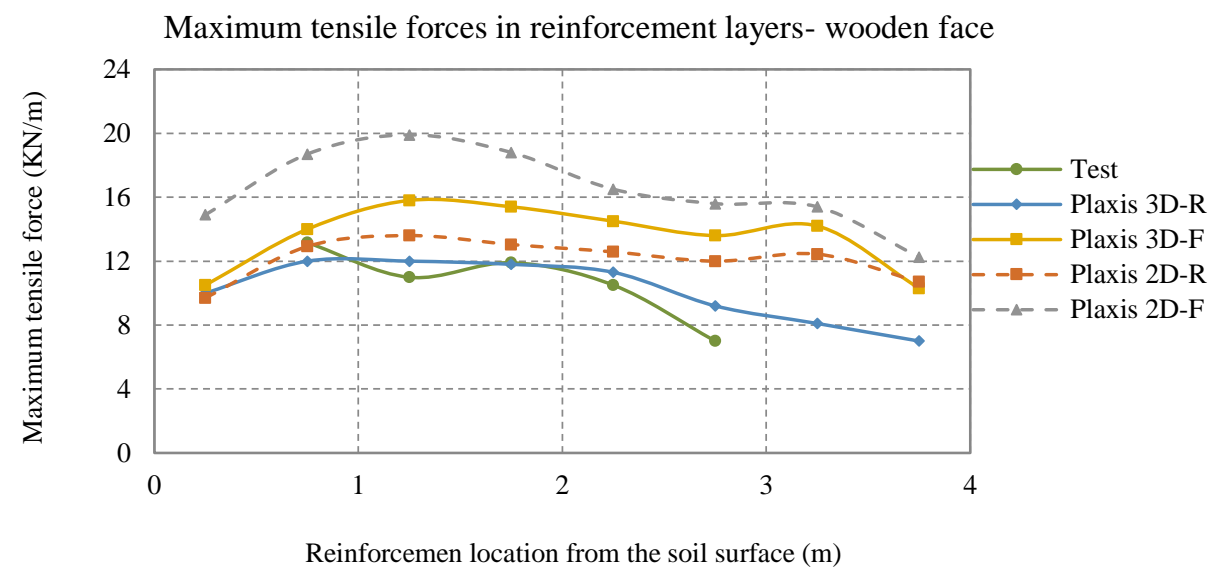

a)

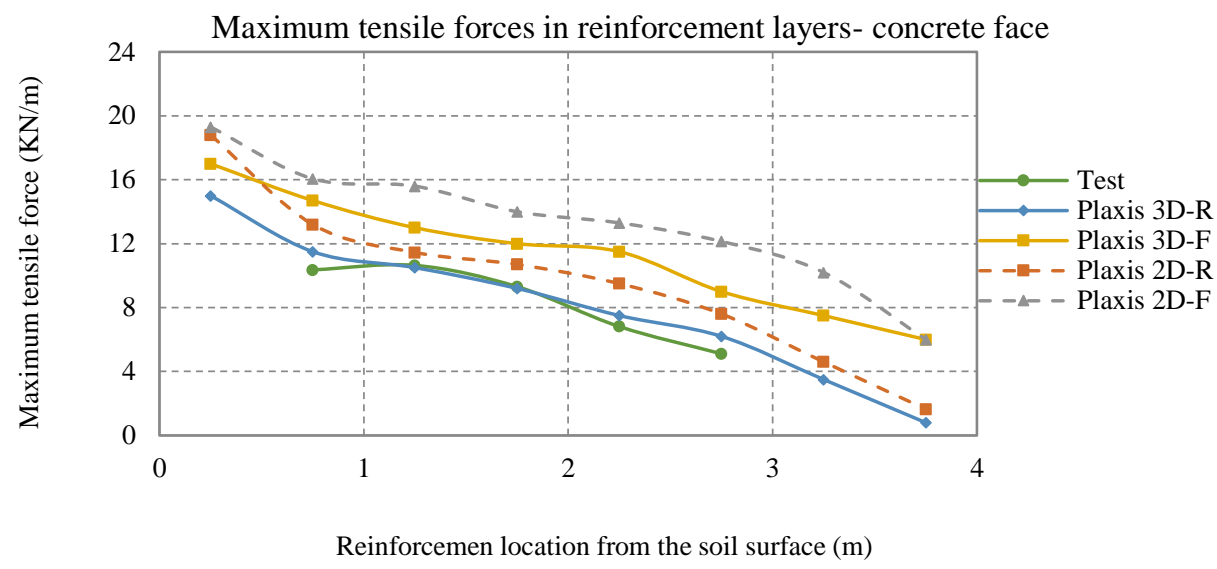

b)

Fig. 5: Maximum tensile loads on reinforcement layers in measurement and Plaxis analysis after applying the strip footing load $(300 \mathrm{kPa})$; a) wooden face, b) conceret face.

Table 2 presents the sum of maximum tensile forces from $2^{\text {nd }}$ to $6^{\text {th }}$ layer in test and Plaxis $2 \mathrm{D}$ and $3 \mathrm{D}$ analysis. The difference between the 2D numerical analysis and test results is $40 \%$ before considering the horizontal restriction in the strip footing load and reduces to $15 \%$ after applying the horizontal retriction for strip footing load for both the concrete and wooden face. For 3D numerical analisys these differences are around 30\% and 6\% for the concerete and wooden face. The difference between the 2D and 3D numerical analysis in wooden and concrete face in this table is around $10 \%$. This 
difference may show the effect of sidewalls friction. From Table 2, 3D numerical analysis shows better results than $2 \mathrm{D}$ by considering the full 3D behaiviour of the models.

Table 2: Differences between the maximum tensile forces on reinforcement layers in test and Plaxis analysis.

\begin{tabular}{|l|c|c|c|c|c|}
\hline Models & $\begin{array}{c}\Sigma \mathrm{T}\left(2^{\text {nd }}-6^{\text {th }}\right)-P l a x i s(2 \mathrm{D}) \\
(\mathrm{KN} / \mathrm{m})\end{array}$ & $\begin{array}{c}\Sigma \mathrm{T}\left(2^{\text {nd }}-6^{\text {th }}\right)-\mathrm{Plaxis}(3 \mathrm{D}) \\
(\mathrm{KN} / \mathrm{m})\end{array}$ & $\begin{array}{c}\Sigma \mathrm{T}\left(2^{\text {nd }}-6^{\text {th }}\right)-\mathrm{Test} \\
(\mathrm{KN} / \mathrm{m})\end{array}$ \\
\hline & Free & Restricted & Free & Restricted & \\
\hline Concrete face & 71.1 & 50.15 & 60.2 & 44.9 & 42.23 \\
\hline Wooden face & 89.5 & 64.14 & 73.3 & 56.3 & 53.5 \\
\hline
\end{tabular}

\section{Conclusion}

2D and 3D Finite element analysis results were compared with the experimental full-scale mechanically stabilized earth walls under strip footing load in this study.

It was found that the composite behavior of the soil-geosynthetic in full-scale walls can be modeled under strip footing load by considering the horizontal restriction of the strip footing in the loading step. The comparison between the maximum tensile loads in the test results and numerical analysis showed a $30 \%$ larger load in the calculations for horizontally free condition in 3D numerical analysis and only $6 \%$ larger assuming a horizontally restricted condition for strip footing load. For the wall deflection there is $8 \%$ difference between the 3D numerical analysis and test results using the horizontally restricted condition for strip footing load. The horizontal restriction for strip footing load showed better results on the soil-geogrid interaction especially under the strip footing load and consequently an increase in surcharge load will lead to a smaller change in the strains and consequently less deflection in the wall compared to an analysis without horizontal restriction. Both the numerical and test results show that, the more rigid concrete facing panel has the maximum horizontal earth pressure on a higher point on the wall than the wooden wall. It indicates that for the flexible face after applying the strip footing load, there is deeper failure zone than the rigid face. The horizontal displacements of the wall, the lateral earth pressure and the reinforcement tensile load distribution are in good agreement with the 3D numerical analysis by considering the horizontal restriction for strip footing load. In the tests also there was a limited influence of side wall friction.

\section{References}

[1] K. Kazimierowicz-Frankowska, "A case study of a geosynthetic reinforced wall with wrap-around facing," Geotextiles and Geomembranes., vol. 23, no. 1, pp. 107-115, 2005.

[2] D. T. Bergado, C. Teerawattanasuk, "2D and 3D numerical simulations of reinforced embankments on soft ground," Geotextiles and Geomembranes., vol. 26, no. 1, pp. 39-55, 2008.

[3] K. Hatami, R. J. Bathurst, "Development and verification of a numerical model for the analysis of geosynthetic reinforced soil segmental walls under working stress conditions," Canadian Geotechnical Journal., vol. 42, no. 4, pp. 1066-1085, 2005.

[4] K. Hatami, R. J. Bathurst, "Numerical model for reinforced soil segmental walls under surcharge loading," ASCE Journal of Geotechnical and Geoenvironmental Engineering., vol. 132, no. 6, pp. 673-684, 2006.

[5] M. S. Won, Y. S. Kim, "Internal deformation behavior of geosynthetic-reinforced soil walls," Geotextiles and Geomembranes., vol. 25, no. 1, pp. 10-22, 2007.

[6] D. T. Bergado, J. C. Chai, N. Miura, "FE analysis of grid reinforced embankment system on soft Bangkok clay," Computers and Geotechnics., vol. 17, pp. 447-471, 1995.

[7] R. Karpurapu, R. J. Bathurst "Behavior of geosynthetic reinforced soil retaining walls using the finite element method," Computers and Geotechnics., vol. 17, pp. 279-299, 1995.

[8] J. C. Chai, N. Miura, D. T. Bergado, P. V. Long, "Finite element analysis of geotextile reinforced embankment failure on soft subsoil," Geotechnical Engineering Journal., vol. 28, no. 2, pp. 249-276, 1997.

[9] R. K. Rowe, S. K. Ho, "Horizontal deformation in reinforced soil walls," Canadian Geotechnical Journal., vol. 35, no. 2, pp. 312-327, 1998. 
[10] Ph. Gotteland, J. P. Gourc, C. Jommi, R. Nova, "Finite difference analysis of geotextile reinforced earth walls," in Proceedings of EuroGeo 1., the 1st European Geosynthetics Conference, Maastricht, the Netherlands. pp. 503-510, 1996.

[11] B. Huang, R. J. Bathurst, K. Hatami, "Numerical study of reinforced soil segmental walls using three different constitutive soil models," ASCE Journal of Geotechnical and Geoenvironmental Engineering., vol. 135, no. 10, pp. 1486-1498, 2009.

[12] M. Ehrlich, S. H. Mirmoradi, "Evaluation of the effects of facing stiffness and toe resistance on the behavior of GRS walls," Geotext. Geomembr., vol. 40, pp. 28-36, 2013.

[13] M. Ehrlich, S. H. Mirmoradi, R. P. Saramago, "Evaluation of the effect of compaction on the behavior of geosynthetic-reinforced soil walls," Geotextiles and Geomembranes., vol. 34, pp. 108-115, 2012.

[14] S. H. Mirmoradi, M. Ehrlich, "Modeling of the compaction-induced stresses in numerical analyses of GRS walls," International Journal of Computational Methods (IJCM), Special Issue on Computational Geomechanics, 2014.

[15] S. H. Mirmoradi, M. Ehrlich, "Modeling of the compaction-induced stress on reinforced soil walls," J. Geotext. Geomembr., vol. 43, no.1, pp. 82-88, 2015.

[16] M. I. M. Pinto, T. W. Cousens, "Geotextile reinforced brick faced retaining walls," Geotextile and Geomembranes., vol. 14, pp. 449-464, 1996.

[17] M. I. M. Pinto, T. W. Cousens, "Modelling a geotextile-reinforced, brick-faced soil retaining wall," Geosynth Int vol. 6, no. 5, 1999.

[18] A. L. Shinde, J. N. Mandal, "Behavior of reinforced soil retaining wall with limited fill zone parameter," Geotech Geol Eng., vol. 25, pp. 657-672, 2007.

[19] S. Mittal, K. G. Garg, S. Saran, "Analysis and design of retaining wall having reinforced cohesive frictional backfill," Geotech Geol Eng,. vol. 24, pp. 499-522, 2006.

[20] H. Ahmadi, M. Hajialilue-Bonab, "Experimental and analytical investigations on bearing capacity of strip footing in reinforced sand backfills and flexible retaining wall," Acta Geotech., vol. 7, no. 4, pp. 357-373, 2012.

[21] D. Pachomov, L. Vollmert, A. Herold, "Der Ansatz des horizontalen Erddruckes auf die Front von KBE-Systemen Sonderheft Geotechnik," Deutsche Gesellschaft für Geotechnik e.V. DGGT, Esen, S., pp. 129-136. 2007.

[22] Z. Yang, "Strength and deformation characteristics of reinforced sand," Ph.D. dissertation, Univ. of California, Los Angeles.

[23] F. Schlosser, N. T. Long, "Long Recent results in French research on reinforced earth," J. Constr. Div., vol. 100, no. 3, pp. 223-237, 1974.

[24] J. T. H, Wu, T. Pham, "Load-carrying capacity and required reinforcement strength of closely spaced soilgeosynthetic composites," J. Geotech. Geoenviron. Eng. ASCE, vol. 139, no. 9, 1468e1476, 2013.

[25] H. Ahmadi, A. Bezuijen, "Numerical analysis of full-scale mechanically stabilized earth (MSE) walls under strip footing load," In Proceedings of EuroGeo 6., the 6st European Geosynthetics Conference, Ljubljana, Slovenia. 2016.

[26] R. B. J. Brinkgreve, P. A. Vermeer, "Plaxis: Finite Element Code for Soil and Rock Analyses, version 8," Balkema, 2002.

[27] DIN, Geotextiles-Wide width tensile test (DIN EN ISO 10319:2008), Deutsches Institut für Normung e.V.

[28] C. P. Wroth, "The interpretation of in situ soil tests. 24th Rankine Lecture," Geotechnique., vol. 34, no. 4, pp. 449489, 1984. 